China Perspectives

66 | July- August 2006

Varia

\title{
China-Taiwan: Young People Confront Their History
}

Samia Ferhat

\section{OpenEdition}

12 Journals

Édition électronique

URL : http://journals.openedition.org/chinaperspectives/1038

DOI : 10.4000/chinaperspectives.1038

ISSN : 1996-4617

Éditeur

Centre d'étude français sur la Chine contemporaine

\section{Édition imprimée}

Date de publication : 1 juillet 2006

ISSN : 2070-3449

\section{Référence électronique}

Samia Ferhat, «China-Taiwan: Young People Confront Their History », China Perspectives [En ligne], 66 | July-August 2006, mis en ligne le 01 août 2008, consulté le 21 décembre 2020. URL : http://

journals.openedition.org/chinaperspectives/1038; DOI : https://doi.org/10.4000/chinaperspectives. 1038

Ce document a été généré automatiquement le 21 décembre 2020.

(C) All rights reserved 


\title{
China-Taiwan: Young People Confront Their History
}

\author{
Samia Ferhat
}

Relations between the People's Republic of China and Taiwan are often considered particularly delicate, not to say conflicting. Generally speaking, the observer's attention is focused on the factors that separate the two sides and threaten to bring them to armed conflict. Yet, in light of the increasingly significant development of their trading, academic and cultural relations, it seems useful also to study all that helps to bring the two sides together, and thus to throw light on points of contact between them.

2 While the present dispute dates back now over fifty years, and while no political resolution has so far been identified, links between the two societies have been formed. In general, a political settlement is required first, before two human collectivities that have been divided by war can be reunited. But where these cross-Strait relations are concerned, a contrary dynamic seems to have been established; and that allows us to adopt a more positive view of developments ahead.

3 To speak of reconciliation between the People's Republic and Taiwan may seem premature, even unrealistic. Yet, this prospect has been raised several times over by political leaders in Taipei as in Peking. And Chinese and Taiwanese engineersdreamers, of course-have gone so far as to imagine building a tunnel that would link the island to the mainland, a project they judge technically feasible ${ }^{1}$. What an ideal vision this is, in terms of peace and reconciliation! It would be a real umbilical cord, joining at last these two countries, these two peoples, across five decades of open hostility.

4 In this state of mind, and in the conviction that peace rests upon a change of mentality and is built on the basis of a pacific and open perception of other people, I have embarked upon a survey of Chinese and Taiwanese youth. So far, 40 people have taken part: 30 in France and ten in mainland China. Ten more interviews will be conducted in Taiwan. The participants, all university students, are aged between 23 and 33. Each is 
invited, following a preset questionnaire ${ }^{2}$, to speak about the same period of Chinese history: the four decades between 1910 and $1950^{3}$.

While the development of economic and cultural links is favourable to a possible process of reconciliation, it seems that reconciliation also requires people to look back less harshly on the past and to accept a common account of those tragic events that have led to bitterness and war. Thus the questions have been framed to bring the participants to draw upon a generality of data arising both from their historical knowledge and also from a collective and individual store of memory. My aim in approaching these young people, in addition to highlighting the dominant historical account in China and Taiwan, is to understand the perception that each group has of this moment of history and to identify how individuals represent it to themselves. How do they imagine the Others? How do they see themselves in sharing their stores of history and memory with the Others? Can they imagine a common future within an entirely peaceful social and political context?

Two rival political entities ...

6 The end of the Second World War, with the capitulation of the Japanese armed forces and their withdrawal from the territories of mainland China and Taiwan, allowed the renewal of hostilities between Chinese Communists and Nationalists. The two sides found it impossible to reach a compromise settlement. They confronted each other as two antagonistic political entities: the People's Republic of China, based in Peking, and the Republic of China, based in Taipei. Both governments claimed to be the legitimate representatives of the Chinese people in their totality.

International recognition was awarded first of all to the Nationalist government led by Chiang Kai-shek. In the wake of decolonisation, there was a change in the international context; the process of normalising relations between Washington and Peking began; and both led in 1971 to a reversal of the situation. Indeed, Peking became a permanent member of the UN Security Council and was accorded, by most states, that political recognition that had hitherto been denied.

8 At the start of the 1990s, the Taiwanese President, Lee Teng-hui, abolished the Temporary Provisions Effective During the Period of Communist Rebellion that, for forty years, had in a symbolic sense been maintaining the people of Taiwan and the Penghu Archipelago in a state of civil war and provided a basis for Peking's mission to recapture it. This development has allowed the beginnings of a policy of rapprochement with China, reflected in unofficial meetings between two private bodies entrusted with handling technical or commercial questions connected with cross-Strait exchanges. Acting for Taiwan was the Strait Exchange Foundation and for China the Association for Relations Across the Taiwan Strait.

9 In Taiwan, the ending of martial law was coupled with democratisation, which, by allowing pluralism, has also made possible the emergence of a new political discourse, strongly territorialist, articulated by the Democratic Progressive Party (DPP). Independence rapidly came to the forefront of its claims. This was to lead to a break with the constitutional framework of the Republic of China and the proclamation of the Republic of Taiwan. Links with mainland China (including historical and cultural ties) were minimised, thus removing all justification for reunification plans.

10 Yet, it was during the presidency of Chen Shui-bian, the DPP leader, that a new step towards exchanges with the mainland was taken in June 2000. The Three Mini Links (xiao santong) permitted trade, transport and postal exchanges between, on one side, 
the two closest islands of the Archipelago to the mainland, Kinmen and Matsu and, on the other, the province of Fujian: the links were to be direct, with no obligation to pass through Hong Kong or Macao. Further, they allowed Chinese nationals to visit the two islands for trading purposes and, for the first time, the rest of the Archipelago as tourists.

In January 2003, air communications were established. Charter flights were organised for the whole period of the Chinese New Year holiday, to allow Taiwanese businessmen settled on the mainland, and their families, to go back to Taiwan. Yet, citing security reasons, Taipei allowed only Taiwanese airlines to fly the route. In any case, this necessarily meant flying via Hong Kong or Macau and terminating at Shanghai; no other destination was permitted.

In February 2005, charter flights were again made available to Taiwanese businessmen. The scope here was far more significant than in 2003. For one thing, authorisation for flights to Taiwan was now extended to mainland companies. And such flights could for the first time be direct, with no obligatory stopovers in Hong Kong or Macau. Destinations on the mainland could be Peking, Shanghai or Canton. In Taiwan they could be Taipei or Kaohsiung ${ }^{4}$. The success of these direct flights was so great that the authorities on both sides of the Strait expressed the wish to continue the experiment beyond the holiday period, beginning with cargo flights ${ }^{5}$.

Additionally, the spring 2005 visits to China by Lien Chan, then President of the Kuomintang (KMT), and James Soong, President of the People First Party (PFP), came to have a dynamic effect on the development of cross-Strait relations ${ }^{6}$.

... strides along the path to reconciliation?

President Chen Shui-bian has twice expressed a desire for reconciliation with mainland China. In May 2000, on the occasion of his inaugural address, he explained the new orientation that he aspired to give to cross-Strait relations. His pledge, known as the Four No's and One Without (sibu yi meiyou) ${ }^{7}$, was conceived, he said, in an environment of goodwill, a state of mind on both sides of the Strait that was favourable to reconciliation and to the achievement of sustainable peace. In February 2005, when the defeat of the Democratic Progressive Party in the local elections pushed the government towards reaching a consensus with opposition leaders better disposed towards Peking, Chen appealed anew for progress towards cross-Strait reconciliation and co-operation ${ }^{8}$.

A few months later, a Chinese Communist Party theorist was to declare that the Party's policy was that of reconciliation with Taiwan?.

Of course, one may doubt these politicians' sincerity or, at the very least, remembering that their intentions are strictly political, one should not attach undue weight to their declarations. This will help to understand Chen's apparent changes of heart. Several times over, he has challenged the policy of appeasement towards the mainland. In particular, on February 27th 2006, he went back on the commitment expressed in the Four No's and One Without, announcing that the Council for National Unification would "cease to function" and that its Guidelines would "cease to apply". Caught off balance, the United States had succeeded only in negotiating a softening of the terminology. The word "abolish" had not been used, in deference to Chinese sensitivities ${ }^{10}$. Chen's initiative will undoubtedly give rise to new tensions with Peking as well as with those Taiwanese political groupings opposed to independence. 
17 Even so, these recurrent tensions have not so far prevented the emergence of an embryo form of civil society linking the peoples of the two territories. The Taiwanese mainland community has grown considerably. It is particularly extensive in the Shanghai region where people often refer to the existence of a "little Taiwan"11. Mixed marriages are frequent, particularly between Taiwanese men and mainland women. This human community which, in a sense, embodies the link between the two societies is a source of political pressure. Indeed, the direct flights that began in February 2005 owed a great deal to sustained pressure exerted by Taiwanese entrepreneurs living in China. The same can be said of the gradual relaxation of Taiwanese laws governing mixed marriages, to take into account the interests of mainland spouses. Such links are made easier by the fact that the two peoples share so much of their historical and cultural heritage.

A shared history ...

18 The Civil War and the splitting up of the territories are still at the forefront of memory in mainland China. Recollections are passed on to the younger generation in the stories told by elder generations. In Taiwan, outside the mainlanders' families, these events belong in imagined memory, part of the history of the national community within the context of the state's particular destiny, in this instance that of the Republic of China. And through novels or films, and coloured by patriotic feeling, the memory takes shape; and it has been able to impart emotional and affective substance to the official history. For young Chinese people, looking back over these moments of history does nothing to disturb the feeling of national belonging; but the issue for the Taiwanese proves far more sensitive. Looking back over the history of the Republic of China, with reawakened memories of the break with the mainland, amounts to a bewildering exposure to a complex and now strongly politicised identity.

The question of the connection with China springs unavoidably to the minds of young people in Taiwan, bringing in its train a series of questions. What share of loyalty is owed to the land of one's birth, or to one's country of origin? Where do people stand in regard to this moment of history, when in Taipei the question of independence has become, with the passing of the years, a question of honour, and of pride in the national community? And then, what should they make of those chevaleresque epics about warring kingdoms? of the military and political greatness of the Qin Dynasty? Of the cultural influence of the Tang Dynasty? of the humiliation represented by the Opium Wars? Of dignity regained on the day the Republic of China was formed, or of the feeling on hearing its national anthem today? Of the words they pronounce, or the Chinese characters they draw? Questioning the collective, family or individual career must, in the depths of the memories aroused, affect the perceptions that all young people make of their own identities and futures, within an unusually troubled political and geostrategic context.

... multifarious representation

Those taking part in the survey were born between 1972 and 1982; they are aged between 23 and 33. While all their families originate from mainland China, they have grown up with the policies of reform and openness launched in 1978 while benefiting, unlike their parents, from some measure of material comfort. Although they did not personally witness the political violence of the Maoist period, all but the youngest can look back to the Tian'anmen events of June 4th 1989. The questionnaire does not address the years following the formation of the People's Republic of China. Yet, 
recalling family experience inevitably draws these young people into a critical analysis of contemporary political history. Those participants questioned in Paris are usually more restrained in their views, the drawbacks of the Maoist period being moderated by pragmatic considerations linked to the sociopolitical context of the time and minimised in light of the subsequent economic success of the Deng Xiaoping era. By contrast, the people questioned in China have, curiously, far less positive attitudes. Some have no hesitation in condemning the vagaries of Maoism, especially during the Cultural Revolution, and they often regret the absence of freedom of expression or of worship in present-day China. This difference in viewpoint may certainly be explained by geographic distance. It is as though the annoyances and the disappointments of everyday life in a foreign land has bolstered, among the students settled in France, feelings of loyalty and patriotic attachment to their country of origin ${ }^{12}$.

of the Taiwanese participants, the oldest were born well before martial law was lifted. They received a traditional education tending to emphasise the feeling of belonging to the Chinese nation. Some can remember that their school textbooks still spoke of the recapture of the mainland as an ideal to be achieved ${ }^{13}$. It was often at home that they learned that such discourse was somewhat fanciful. As young adults they witnessed the coming to power of Lee Teng-hui. Attracted by the prospects of openness that the new political leadership allowed them to glimpse, they mostly joined the emancipation movements of the 1990s, and were then caught up in the turmoil of questioning-of their nationalism, of their identity-that was to follow. The younger ones, who were barely five years old at the time when martial law was lifted, grew up in a society marked by the division created between Taiwanese identity and Chinese identity. At the time when Chen Shui-bian was embarking on his first presidential term, they were just coming out of adolescence. Yet, their perspectives on the history of the split and on the question of relations with China are apparently more distanced, less emotionally involved, than those of their elders. When it comes to the young people living in France, their lives abroad seem also to have affected the feelings connecting them to the country of their birth ${ }^{14}$. Several of them remarked, indeed, that while they saw themselves before leaving Taiwan as having both Chinese and Taiwanese identity, their experience of living in France (for reasons that I shall mention later on) had brought them to favour a strictly Taiwanese identity for the future.

Faced with this moment of history, the participants will spontaneously favour several events that, for them, are the most meaningful: the formation of the Republic of China, the War of Resistance against Japan, and the Civil War. They will also refer back with pride to some dynasties of ancient China. Lastly, they will speak of those Others, living on the mainland or in Taiwan, other people whom often they have met but who remain, however, unfamiliar.

The Republic of China The participants are agreed on one point: they acknowledge the 1911 Revolution as one of the most significant events of the period. Yet, the understanding they have formed of this moment of history differs somewhat from person to person.

For the Chinese, the 1911 Revolution, which brought about the creation of the Republic of China, put an end to the humiliation undergone at the hands of Western countries. They had taken advantage of the weakness of the Qing Dynasty to occupy significant areas of the country during the latter half of the nineteenth century and had acquired, by a series of military victories over the Chinese, extensive privileges. Thus, many will 
recall with strong feelings the derisive phrase once used for their country, the "Sick Man of East Asia"15. These young people see the Republic of China as having given back dignity and hope to the Chinese people. They see the new Republic, which had brought to an end the dynastic system, as promising political and social development that would steadily bring their country towards modernity-then envisaged as a Western achievement.

This feeling of national humiliation is also mentioned by the Taiwanese, though with markedly less bitterness. It seems that they prefer to dwell on the intellectual, political and cultural renewal that the Republic of China ushered in. Though they also consider that it brought new hope for China, they are less concerned with washing away the humiliations inflicted by the West than with building a powerful and prosperous country.

The overwhelmingly positive perception that they have of the 1911 Revolution brings all of them to pick out Sun Yat-sen, among all the political figures of the time, as the man they consider as "Father of the Nation" (WW, guofu). The nation itself they are unanimous in seeing as linked, at that time, to the institutions and the political context of the Republic of China. Similarly, they are as one in regretting the failure of the state and the society that it had set out to create. They attribute this project, often quite exclusively, to the efforts of Sun Yat-sen. They consider it to have been aborted in 1925, the year of his death. The Republic of China that once included the whole of the Chinese nation and extended across the whole of its territory is, in their eyes, nonexistent today. Of course, there is still a political entity called the "Republic of China", which everyone agrees is situated in Taiwan; but, as they describe it, it appears devoid of its original national substance. It no longer corresponds to the Chinese nation in the human and territorial dimension of the times. In the same way, it no longer seems really associated in their minds with the idealised personality of Sun Yat-sen, but rather with the power struggle that broke out on his death within the Kuomintang, as well as with the Civil War and the territorial break-up that followed it. Nevertheless, it is still historically significant and, for the Taiwanese, has retained a cultural meaning that influences most of them deeply.

Indeed, unlike the People's Republic, which Maoism has distanced from the canons of the Chinese cultural tradition, the Republic of China, eager to affirm its legitimacy in representing and perpetuating the essence of the nation, has set a special value on them. The policy of emphasising Chinese culture that was adopted in the early 1950 s in Taiwan also helped to spread the traditions. These cultural values, implanted from the early years of schooling, are a source of pride to the Taiwanese students. For this reason they all regret the simplified form of writing that has been introduced on the mainland, with the mutilation it has inflicted on Chinese characters. They are also surprised by a certain coarseness of language, which they generally put down to the influence of Maoist rhetoric. When it comes to interpersonal relationships, these seem to be lacking in the gentleness and subtlety appropriate to the standards of conduct prescribed by the Confucian heritage ${ }^{16}$. They ascribe the destruction of these moral values (which they often call meide (WW) or "absolute virtue") to the period of the Cultural Revolution.

Thus, all of them are agreed on one conclusion, that the political project of the Republic of China was a failure, ending in the break-up of 1949. Nevertheless, it seems that this break-up is perceived differently by the Chinese and the Taiwanese. The Chinese 
particularly deplore the splitting up of the nation, which they see in terms of its human and territorial consequences: they say China has been brutally despoiled of one of its provinces. Whereas for the Taiwanese, the break-up is hardly seen at all in nationalist terms, but rather in terms of history and morality. It is as though they felt themselves entrusted with a system of values and a destiny that the mainland Chinese have abandoned.

For the Taiwanese, the Republic of China is now strictly limited to the territory and the people of Taiwan-even though, as I have pointed out, it is still invested with a historical and cultural dimension transcending these geographical limits. Nevertheless, state symbols always appeal strongly to young people's emotions: they say they are moved to hear the national anthem, and to see their flag being raised. And they would like such symbols to be more visible, particularly during sports contests at the international level where Taiwanese athletes are competing. As things are, to avert the anger of Peking, the Taiwanese teams are saluted under the colours of an "Olympic Flag", to the strains of an "Olympic Anthem", specially prepared for such occasions.

Yet, and this is where ambiguousness creeps in, most would prefer to see the name Taiwan printed on their passports, not the Republic of China. As they point out, the mention of China can cause confusion in the minds of foreign hosts who, mistaking them for citizens of the People's Republic of China, can judge them by a set of not always favourable prejudices ${ }^{17}$. Similarly, they are often inclined to claim an exclusively Taiwanese identity, to the detriment of the attachment they feel for the historical and cultural dimension of the Republic of China. Indeed, to acknowledge citizenship of the Republic of China amounts, for some of them, to validating the nationalist discourse that they have heard in the mouths of their Chinese fellow-students ${ }^{18}$. Thus, many will say they have joined the pro-independence movement, in order to show that the solution of unification with China is far from being achieved. In fact, putting a distance between themselves and the Chinese world is the equivalent, for some, to claiming a right, that of deciding Taiwan's future. It would seem as though the strength of the nationalist sentiments encountered among Chinese students, often asserted in unsolicited speeches about the future reunification of Taiwan with China, inclines these young Taiwanese to favour symbolic referents that they know the Chinese students do not share. So they insist on belonging to a strictly Taiwanese community, the corollary of a national identity strictly limited to the frontiers of the island. Their approach is to favour that which distinguishes them from the Others and consequently to minimise the influence of the common heritage associated with Chinese civilisation. This acceptance/rejection dynamic in relation to the Chinese heritage seems to have especial force for those settled abroad, where the confrontation with the Others is more destabilising, more weakening. Many participants tell me that they have never felt themselves so Taiwanese as they do since they arrived in France and started meeting Chinese students ${ }^{19}$.

The War of Resistance Against Japan

31 The War of Resistance Against Japan is the second of the historical events of the period 1910-1949 picked out by the participants. Curiously, what they consider historically important is neither the invasion of China by Japan nor the defeat of Japan at the end of the Second World War, but rather the success of the War of Resistance (kangri zhanzheng shengli). 
32 All our participants express the same feelings on this subject: the shame of being invaded, anger and sadness over the atrocities committed by the Japanese soldiers, particularly in Nanking in 1937, pride in the alliance between nationalist and communist troops in the struggle against the occupying forces and the joy of victory. Taiwanese and mainland Chinese, both sides refer explicitly to the feeling of national pride over this outcome. The Taiwanese appeal to what they call their "nationalist heart" (minzuxin) ${ }^{20}$ to fuse with this moment of history and make it completely theirs. At this point in the questionnaire, it is as though the China/Taiwan distinction was no longer real in their minds. The majority of the Taiwanese, whether they be islanders or mainlanders, identify wholly with the protagonists in this historical episode. Yet, at that time, Taiwan was a Japanese colony and its inhabitants, subjects of the Japanese Emperor, were having to fight alongside the Japanese troops ${ }^{21}$. Also, the explanations they offer for the defeat of the Japanese are invariably couched in the language of nationalism. In particular, they insist that it is impossible for any invaders, whoever they may be, to defeat a united people determined to drive them out. The Pacific campaign waged by the Americans and the use of the atomic bombs on Hiroshima and Nagasaki are not systematically mentioned or, if they are, not until much later in their replies.

This community of feeling is also found in their evaluation of the Civil War.

The struggle between the Nationalists and the Communists

Among the events of the period 1910-1950, this one, for the students, is the most regretted. Some, both Taiwanese and Chinese, describe the war as "fratricidal" (da ziji ren). Mostly their accounts of it are lucid, though not necessarily faithful to official interpretations. Thus, according to them, the war came about because the political leaders of the time, Mao Zedong and Chiang Kai-shek, found it impossible to reach a negotiated solution. For that they would have to have made concessions, and to have relinquished some of their prerogatives and a portion of their power. However, the young people attribute responsibilities differently. The Chinese interviewed in France more commonly condemn Chiang Kai-shek's ambition; whereas some of those who spoke to me in China did not hesitate to mention the conception, in their view exaggeratedly monopolistic, that Mao adopted of the exercise of power. The Taiwanese see the question more objectively and impute the struggle to the overweening ambition of both men. Mostly they emphasise the cynicism of politicians, and the misfortunes that this can lead to. By contrast, they venerate the figure of Sun Yat-sen: in their imagination, as in Chinese notions as well, he appears untainted by any political manoeuvring and truly devoted to the good of the nation.

Regrets surface more precisely regarding the situation following the Civil War. For the Chinese, it led to the break with Taiwan and so, as I have already pointed out, to the splitting up of the nation in human and territorial terms. They see this state of affairs as regrettable and, in particular, as difficult to resolve. While they are mostly favourable to reunification, they reject any prospect of war; yet, they are agreed in judging that it could happen. They stress also that human and material losses would be considerable on both sides, but that China, unlike Taiwan, benefits from territorial and demographic power that would enable it to absorb the shock.

Among the Taiwanese, the analysis is again particularly ambiguous. Admittedly, the Civil War is seen to have led to the break of 1949 , but also and above all as having plunged China, because of the Communist victory, into a new and particularly harmful 
political and social organisation. They are sorry that the country subsequently fell behind in economic development; and they deplore the political violence and the damage inflicted upon the cultural tradition. They think that China, without the tragedy of war and the errors of Maoism, would have become a world power to which perhaps, though this is not openly expressed, they might have felt proud to belong. This nostalgia for a powerful, prosperous and respected China can be sensed also in their overall view of its history.

Deep respect for ancient history

The period of China's history that our participants have least pleasure in dwelling upon is precisely that concerned in the questionnaire. It makes them sad, disappointed, regretful. On the other hand, they are happy to talk about ancient history with particular admiration for the Qin and Tang Dynasties. While they acclaim in the Tang Dynasty its cultural and artistic influence, they point to the political genius of the man who founded the Qin Dynasty, Emperor Qin Shihuang. They praise his achievements and, especially, the unification of the territory and the system of writing. Though they do not shut their eyes to the authoritarian and violent way in which he exercised power, they justify it by the greatness of what was achieved.

This judgement may seem surprising, especially in light of the criticisms made of present-day political leaders, and of the reservations that the Taiwanese invariably express about the reunification project. Its meaning must be sought, however, in the very particular perception that these students have of what a political leader's mission should be in relation to the national future.

As may be seen from the first results of the survey, these Chinese and Taiwanese students have in common a number of notions about the proposed moment of history. Thus, it is right that we should end by asking how they perceive each other.

Who are the Others?

First of all, they are undeniably capable of imagining the Others and how they feel, even without having ever met them. They are particularly aware of the possibility that all of them, depending on their origins, may have reached different conclusions about the past. They ascribe this to the fact that the teaching of history in their respective societies will have been strongly influenced by politics. They can easily imagine the prejudices that young people of their generation may foster; and they recognise, most of them, that they themselves will have been conditioned by a biased political discourse. Many of them, giving me the details of such propaganda, were keen to stress how insulting were its references to the designated enemy, concluding that it was better not to repeat them.

41 For those studying abroad, the opportunities for encountering the Others are quite frequent. The students often find themselves in the same educational institutions, and also sometimes they share the same accommodation. It is not unusual for them to find things in common; and friendships are all the easier to make if both sides carefully avoid delicate questions. While they may discuss the political situation in China or Taiwan, they will prefer not to dwell on possible solutions to the cross-Strait relationship, without being sure of holding the same, shared convictions.

Yet, if there is no intention of becoming friends, each side may be less tolerant of the other's susceptibilities. As I said earlier, several of the Taiwanese had been offended by what they considered the arrogance of their Chinese fellow-students, an arrogance reflected in a heightened nationalism that was immovably set upon the reunification of 
Taiwan to China. In situations of this kind, the Others then appear in all their otherness.

Some of the Taiwanese, indeed, deny any membership of a community that would also include the Chinese ${ }^{22}$. They expand on this assertion by pointing out all that separates the peoples on opposite sides of the Strait: their language, the way they are, the way they behave... While they recognise that they too speak Mandarin, they emphasise nevertheless those features of their Mandarin that make it distinct from that spoken on the mainland. On top of that, as I have described before, they mention a whole range of values associated with the Chinese cultural tradition that they say they cannot discern in their Chinese fellow-students. So much so that they feel a distance, an inability to form any personal relationships with them. In general, they use the term gehe (WW), which may be translated as "barrier".

Curiously, these are the same arguments that most of the young Chinese use to show how both sides do belong to the "same family". They consider that both sides have in common their language, culture, civilisation; above all, they consider that a blood relationship has been handed down to them across the generations. And yet, the same people will not hesitate, when they are pressed a little further about their territorial origins, to differentiate themselves from the people of some other province, whose dialect, way of life, temperament seem to them so different... Thus, while those from Peking acknowledge themselves also to be $\mathrm{Han}^{23}$, they feel no less different from the people of Shanghai or from Canton! And the Cantonese are themselves quick to mention all those features that distinguish them from other Chinese people. So what can we say about the national minorities? They are presented as unquestionably Chinese, even though not Han, but also displaying cultural features that, often, make them seem somewhat strange or, at least, put them outside what I call the "circle of intimacy".

Following the same logic, the Taiwanese who consider Taiwan as the only human community to which they belong, and who feel themselves absolutely foreign to mainland society, will themselves hasten to make distinctions according to the plurality of communal loyalties present across the island. Thus, mainlanders are not necessarily part of that circle of intimacy; they often find close relationships easier with people of Taiwanese origin. Yet, all of these people are considered as Han and, above all, as Taiwanese.

If these young people are not yet ready to feel themselves part of the "same family", can they look ahead into a peaceful future, both political and social, in which the Others would have a full place?

How do they envisage their future?

All of them deny any prospect of war, even though they do not consider it to be totally impossible. They are satisfied by the present state of things. Yet, some young Chinese people point out that dragging out the present situation is likely with time to make any settlement of the Taiwan question all the more difficult to resolve. Thus, they hope that reunification will soon be achieved while avoiding, within the limits of the possible, any recourse to armed force. While the Taiwanese can be annoyed by the nationalism of some Chinese people, their lack of enthusiasm for the reunification project never fails to amaze the Chinese-who cannot understand the reluctance of the Taiwanese and are saddened, even offended, by it. Indeed, they have full confidence in China's future, and 
they consider the return of Taiwan as an additional asset to the country, by which its people on both sides could benefit.

The Taiwanese, however, are troubled about their future and that of their island. Most of them are pained by the domestic political wrangling in Taiwan. In particular they condemn the politicians for manipulating people's community loyalties. Most of them consider that the radical pro-independence campaigners propound arguments that take no account of Taiwan's security or of the reality of Peking's superior military might.

They often feel themselves torn between policies insisting upon Taiwan's cultural individuality, and cultural referents that are mainly Chinese. They find it difficult to see themselves within one basic identity; and the confidence that they find among most of their Chinese counterparts only intensifies their unease. Unification is envisaged, but exclusively in the long term. They would like, beforehand, to be assured of an equal level of economic development in both territories, and of the establishment of a democratic system on the mainland.

All of them, on both sides, wish that they knew each other better; and they condemn their respective societies for not making more information available. The Chinese, especially, would like to visit Taiwan more easily. They appear very curious about this land and its people: they would wish to welcome them, like the prodigal son, to the blossoming openness and development that, for several years now, has been transforming China.

51 Translated from the French original by Philip Liddell

\section{NOTES}

1. "China, Taiwan experts discuss cross-Strait tunnel", Newswrap programme on Radio Television Hong Kong (RTHK) audio website, November $8^{\text {th }} 2005$.

2. Until the survey is complete it will not be possible to report the content of the questionnaire; this must wait until a future piece of work. The present article reports the preliminary results of those interviews already conducted.

3. To simplify, we may pick out within this period the following events: 1) The Wuchang uprising on October $10^{\text {th }} 1911$, later known as the Xinhai Revolution, which led to the formation of the Republic of China in Nanking in January 1912, its government initially presided over by Sun Yat-sen; 2) The Northern Expedition begun in 1926 by the Nationalist government led by Chiang Kai-shek, aimed at recruiting or subjugating the warlords; 3) The start of the Japanese Occupation, in Manchuria 1931; 4) The development of political activity by the Chinese Communist Party and the Nationalist government's intensified repression of the Communists (1927-1937); 5) The war of resistance against Japan waged simultaneously by Nationalist forces and the People's Liberation Army led by Mao Zedong (1937-1945). The Civil War, between Nationalists and Communists, from 1945 to 1949. It ended with the formation of the 
People's Republic of China, in Peking, on October $1^{\text {st }} 1949$ and with the withdrawal of the Nationalists to Taipei.

4. “Cross-Strait Relations are Improving Again", The Economist, February $3^{\text {rd }} 2005$.

5. "Taiwan open to talk on cross-Strait - two-way, non-stop - cargo flights", Central News Agency website, Taipei, February $18^{\text {th }} 2005$.

6. However, these two visits caught the governing DPP unawares, and to some extent marginalised the government's role in the dynamic of relations between the two sides.

7. The Four No's: independence would not be declared, the name of the state would not be changed (from Republic of China to Republic of Taiwan or to Taiwan), the concept of "two states" would not be included in the Constitution and, lastly, there would be no referendum on Taiwanese independence. The One Without was that Chen promised not to abolish the National Unification Council or the National Unification guidelines.

“Taiwan-China Relations", in Taiwan Yearbook, Government Information Office, Taipei, 2004, p. 5.

8. “Taiwan President hopes for cross-Strait peace", Central News Agency website, Taipei, February $11^{\text {th }}$ 2005. "Baoji chengxing, liang an jian shuguang” (The circulation of charters, a glimmer of hope for both sides) Zhongguo shibao, February $17^{\text {th }} 2005$.

9. "Chinese theorist says Party seeks reconciliation with Taiwan", Xinhua News Agency website, November $3^{\text {rd }} 2005$.

10. "Hu Jintao pi zhongzhi guotong gangling shi yanzhong tiaoxin" (Hu Jintao criticises the cessation in the application of the Guidelines for National Unification as a serious provocation), Zhongguo shibao, February $28^{\text {th }} 2006$.

11. See Gilles Guiheux, “Taiwanais en Chine: une émigration à rebours?”, Politique Internationale, 104, Summer 2004, pp. 375-386.

12. Time and again, they refer to their "patriotic heart" (WWW, aiguo xin) which means, literally, "the heart that loves the nation". This expression is never used by the Taiwanese.

13. For the processes of socialisation in East Asia, see Edward Vickers and Alisa Jones, History, Education and Identity in East Asia, New York, Routledge, 2005.

14. As the survey in Taiwan has not yet been conducted, it is not possible for the time being to make any comparison with the young people who have not left the country. 15. They say that the origin of this phrase was the sickly appearance of the Chinese consumers of opium. As they rightly point out, the trade in the drug arose from the activities of foreign powers in China.

16. They generally refer to the lunli (WW), which is the comprehensive set of principles governing social duties.

17. The Taiwanese visitor to France is often advised to stress that he or she is from Taiwan, rather than from the Republic of China. If we are to believe the Taiwanese students, it seems that officials in the public services, particularly those in the prefectures, are quick to assume a connection between anyone "Chinese" and the illegal immigrants from the People's Republic. It is often enough to say that one is from Taiwan for the welcome suddenly to become more friendly and relaxed. I don't know how many people have actually had this experience because, in the interviews, the young people relating it invariably begin with "I am told that ..." Nevertheless, it is a familiar story, and one that most of the participants have told me. Whether these representations associated with the mainland Chinese have their origin in observed facts, or whether they have been quite simply invented, they are today firmly lodged in the minds of these Taiwanese students. 
18. As though, for them, anything "Chinese" necessarily refers to the People's Republic. 19. This tendency, seemingly in the majority, is nevertheless not unanimous. Some Taiwanese participants are quick to acknowledge an identity that is Chinese first; and they do not seem to suffer unduly from the nationalism of their Chinese fellowstudents. This point will have to be studied more closely at a later date. Here I am offering only the outlines of the subject.

20. A distinction needs to be made here between the "patriotic heart" cited by the Chinese and the "nationalist heart" referred to by the Taiwanese. In the first case, the young people are speaking of the feelings of loyalty and attachment that bind them to their country, the People's Republic of China. In the second, the Taiwanese give expression to their belonging to the Chinese nation in the historical and cultural senses. One might speak more simply of Chinese civilisation if descent, that is, blood relationship, was not also so essentially valued and did not play such an important part in this feeling of belonging.

21. We should mention that some Taiwanese fighters went to the mainland to join the united front of resistance to Japan.

22. This community is referred to in terms of family: they do not acknowledge the Chinese people's membership of the same family. The phrase used is often: "We are not a family (WWWWWWW, women bu shi yijia ren)."

23. The Han are the ethnic group from which Chinese civilisation is said to have sprung. Today it is one of the five main ethnic groups that make up the Chinese nation.

\section{RÉSUMÉS}

This article reports on the first results of a survey of the new generation of chinese and Taiwanese youth. The aim is to throw light on how these young people see their national history and, in particular, the 1949 split that divided the Chinese community between two armies, and later into two separate political entities. Reaching beyond the official historical account, our interest here is in the young people's perceptions, and the points on which they agree or disagree. Acknowledged or not, a heritage of history and memory is shared between them: we seek to evaluate the part it plays in the political development of relations across the Taiwan Strait. 